\title{
Carboxyhaemoglobin: a possible reference material for haemoglobin assay
}

\author{
JM RIDEOUT, A LOUDERBACK* \\ From the Division of Clinical Chemistry, MRC Clinical Research Centre, Harrow, Middlesex HA1 3UJ, \\ England and *Clinical Chemistry Consultants, PO Box 761, Temple City, California, USA
}

SUMMARY The inter- and intralaboratory quality control of haemoglobin estimation in remote laboratories requires a more rugged control haemolysate than is commercially available. The stabilities of oxyhaemoglobin and carboxyhaemoglobin forms of an ethanediol-containing haemolysate were studied over a three-year period. From the results obtained, carboxyhaemoglobin under nitrogen is proposed as a possible candidate reference material for haemoglobin assay.

Van Assendelft et $a l^{1}$ discussed an interlaboratory trial of quality control in haemoglobinometry and recommended that full intralaboratory control should incorporate the use of concentrated haemoglobin solutions, and that there should be frequent use of haemiglobincyanide $(\mathrm{HiCN})$ reference solutions and checking the $\mathrm{CN}^{-}$content of the reagent.

They measured the haemoglobin content of a commercially available haemolysate (Merz and Dade AG, Bern, Switzerland), kept at $4^{\circ} \mathrm{C}$ over a period of 12 months, at monthly intervals, and using a new bottle of haemolysate for each measurement. During that time, which was the manufacturer's recommended period of stability, the haemoglobin content appeared to decrease by $0.2 \mathrm{~g} / \mathrm{dl}$.

Van Assendelft et al ${ }^{1}$ stressed the need for concentrated haemoglobin haemolysates to be kept free from bacterial contamination and noted that the Merz and Dade haemolysate was membrane filtered to render it sterile. Lewis ${ }^{2}$ has stated that the commercially available lysed blood standards tend to deteriorate during storage with the formation of haemiglobin (methaemoglobin) and denaturation of proteins; furthermore, repeated opening of the bottle for subsampling results in evaporation and contamination with micro-organisms. These observations have been endorsed by our own experience during the World Health Organisation (WHO)sponsored interlaboratory trial of two types of solid state haemoglobinometers ${ }^{3}$ designed for use in developing countries, when the need for a more rugged haemolysate for both intra- and interlaboratory quality control became apparent. Many laboratories, particularly in developing countries, are

Accepted for publication 27 July 1981 at the end of very long and uncertain lines of communication ${ }^{4}$ and quality control materials must be able to tolerate delays in transit at high temperatures.

The preparation of an ethanediol-containing haemolysate is described here, together with findings on the stability of its oxyhaemoglobin and carboxyhaemoglobin forms over a three-year period.

\section{Material and methods}

Waring Blendor (Waring Products Div, Connecticut, USA).

Unicam SP 1800 dual beam spectrophotometer (Pye Unicam Ltd, Cambridge, UK).

Coulter counter S (Coulter Electronics Ltd, Luton, UK).

Hartridge reversion spectroscope (Ealing Beck Ltd, Watford, UK).

$20 \mu$ l SwizzleStick. ${ }^{5}$

Dialysis tubing.

ICSH haemiglobincyanide reference preparation (batch no 50500 , Rijksinstituut voor de Volksgezondheid, Bilthoven, The Netherlands). ${ }^{6}$

ICSH Haemiglobincyanide diluent ${ }^{6}$ (BDH, Poole, UK).

Isoton II and Lyse S (Coulter Electronics Ltd, Luton, UK).

Toluene and ethanediol (ethylene glycol), reagent grade (JT Baker, Phillipsburg, NJ, USA).

Oxygen and carbon monoxide, industrial grade (Matheson, Lyndhurst, NJ, USA).

Stock haemolysate, prepared May 1978, as follows: Cells from 1.51 human blood were washed with $0.9 \% \mathrm{NaCl}$ solution to remove plasma proteins. The washed, packed red cells were lysed by being stored at $-20^{\circ} \mathrm{C}$ overnight and then thawed at $25^{\circ} \mathrm{C}$. This 
procedure was repeated two more times to ensure total haemolysis.

Toluene $(40 \mathrm{ml})$ was added to each $100 \mathrm{ml}$ of haemolysate and mixed (Waring Blendor) for two minutes. The mixture was centrifuged at $2075 \mathrm{~g}$ for 30 min, causing the cellular material to form a tight mat of precipitate between the aqueous haemolysate and the toluene. The toluene was discarded and the haemolysate filtered through glass wool; toluene was again added in the ratio of two volumes of toluene to five volumes of haemolysate. The solutions were mixed and centrifuged as before, the toluene discarded and the haemolysate again filtered through glass wool.

The haemolysate was concentrated in dialysis tubing in a stream of air from an electric fan for $4 \mathrm{~h}$. This gave a solution with a haemoglobin concentration of $29 \mathrm{~g} / \mathrm{dl}$. The volume of concentrated haemolysate was measured and a half-volume of ethanediol was added to make a final solution which contained $33 \% \mathrm{vol} / \mathrm{vol}$ ethanediol.

\section{Oxyhaemoglobin}

Oxygen was bubbled slowly through a well-stirred portion of stock haemolysate solution for $30 \mathrm{~min}$ : $1.0 \mathrm{ml}$ portion of the oxygenated solution were then dispensed into $5.0 \mathrm{ml}$ clear soda glass vials. The contents were overlaid with oxygen, and the vials sealed and stored at $-30^{\circ} \mathrm{C}$.

\section{Carboxyhaemoglobin}

Carbon monoxide was bubbled slowly through a portion of stirred stock haemolysate in an efficient fume cupboard for $30 \mathrm{~min}: 1.0 \mathrm{ml}$ portion were dispensed into $5.0 \mathrm{ml}$ clear glass ampoules, overlaid with nitrogen, sealed and stored at $-30^{\circ} \mathrm{C}$.

\section{METHODS}

\section{Experimental design}

Batches of 88 ampoules of carboxyhaemoglobin and 20 ampoules of oxyhaemoglobin were made available for long term stability testing. The ampoules were divided into four groups to be stored respectively at $-30^{\circ} \mathrm{C}, 4^{\circ} \mathrm{C}$, room temperature (RT $11-26^{\circ} \mathrm{C}$ over the trial period) and $40^{\circ} \mathrm{C}$. Before being placed at these temperatures, the contents of half the ampoules of each group were transferred aseptically into sterile $5.0 \mathrm{ml}$ bijou bottles. There were two reasons for this manoeuvre:

(1) to establish whether storage under gas in a sealed ampoule was really necessary for long-term stability;

(2) to establish whether subsampling caused evaporation losses or contamination by micro-organisms, or both.

Being aware of the problems associated with sample viscosity when using piston-operated air interface micropipettes, ${ }^{7}$ the dilutions of haemolysate were conveniently made using a $20 \mu \mathrm{l}$ positive displacement microlitre diluting device, the SwizzleStick. ${ }^{5}$

\section{Procedure}

The groups of ampoules and bottles were placed at their respective temperatures in May 1978. Visual inspection of ampoules and bottles after $24 \mathrm{~h}$ at $40^{\circ} \mathrm{C}$ revealed no obvious change, but after $72 \mathrm{~h}$ at $40^{\circ} \mathrm{C}$, small "clots" had appeared in the ampoules and bottles of both the oxyhaemoglobin and carboxyhaemoglobin haemolysates; these were not investigated further.

The first haemoglobin measurements were made after three weeks. One ampoule and one bottle were selected at random from each of the $-30^{\circ} \mathrm{C}, 4^{\circ} \mathrm{C}$ and RT groups. The ampoules were labelled $\mathrm{HbCO} 1 \mathrm{~A}$ and the bottles, $\mathrm{HbCO} 1 \mathrm{~B}$, for each temperature. The $-30^{\circ} \mathrm{C}$ and $4{ }^{\circ} \mathrm{C}$ ampoules were allowed to equilibrate to room temperature, when the contents of the ampoules from the three temperatures were transferred aseptically into sterile bijou bottles, appropriately labelled. Dilutions $(1 / 201)$ were made with haemiglobincyanide diluent and a period of two hours was allowed for complete conversion into haemiglobincyanide. ${ }^{8}$ The absorbances of the diluted solutions and of the ICSH haemiglobin reference solution were measured at $540 \mathrm{~nm}$ and the haemoglobin content calculated. Once the dilutions had been made, the capped bottles with remaining contents were replaced at the appropriate temperature.

The second series of measurements was made after 12 wk. Bottles HbCO 1A and 1B from each group were re-examined, in conjunction with another ampoule, $\mathrm{HbCO} 2 \mathrm{~A}$ and bottle, $\mathrm{HbCO} 2 \mathrm{~B}$ from the $-30^{\circ} \mathrm{C}, 4^{\circ} \mathrm{C}$ and $\mathrm{RT}$ groups. The procedure was the same as before, but the dilutions of the RT samples showed an insoluble granular precipitate and were unsuitable for absorbance measurements.

The third series of measurements took place at 38 wk. Bottles HbCO 1A, 1B, 2A and 2B from each group were re-examined, in conjunction with another ampoule, $\mathrm{HbCO} 3 \mathrm{~A}$ and bottle, $\mathrm{HbCO} 3 \mathrm{~B}$ from each of the $-30^{\circ} \mathrm{C}, 4^{\circ} \mathrm{C}$ and RT groups. The RT samples were diluted and visually examined. As the insoluble granular precipitate was present in all of the tubes, their absorbances were not measured and all the ampoules and bottles being stored at RT were discarded.

The final series of measurements took place at 165 wk. All the remaining ampoules and bottles at $-30^{\circ} \mathrm{C}$ and $4^{\circ} \mathrm{C}$ that had not been previously sampled were examined, together with the remaining haemolysates of the earlier studies. 


\section{Results}

The results are shown in Table 1 , each entry representing a single determination on material stored in the manner indicated.

\section{Oxyhaemoglobin haemolysates}

The oxyhaemoglobin haemolysates were examined in the same way as the carboxyhaemoglobin samples but on three occasions only, at 8, 38 and 165 wk. On the second occasion, there was some precipitation when the RT samples were diluted. The results are shown in Table 2.

\section{Presence of haem pigments}

When first sampled, all the ampoules and bottles were examined spectroscopically for the presence of haemiglobin. All the oxyhaemoglobin bottles and previously unopened vials which had been kept at $-30^{\circ} \mathrm{C}, 4^{\circ} \mathrm{C}$ and $\mathrm{RT}$ and $40^{\circ} \mathrm{C}$ contained varying amounts of haemiglobin.

With the carboxyhaemoglobin series, haemiglobin could not be detected in the unopened vials with nitrogen overlay kept at $40^{\circ} \mathrm{C}$, RT and $4{ }^{\circ} \mathrm{C}$, nor in the bottles and vials kept at $-30^{\circ} \mathrm{C}$ for up to $38 \mathrm{wk}$. The bottles at $40^{\circ} \mathrm{C}$, RT and $4^{\circ} \mathrm{C}$ showed varying amounts of haemiglobin. By $165 \mathrm{wk}$, haemiglobin was present in the previously unsampled bottles at $-20^{\circ} \mathrm{C}$ and $4^{\circ} \mathrm{C}$ but could not be detected in the unopened vials at $-20^{\circ} \mathrm{C}$ or $4^{\circ} \mathrm{C}$.

Sulphaemoglobin was not detected spectroscopically in any of the foregoing samples but the possible presence of trace amounts of other pigments was not excluded.

\section{Bacterial contamination}

When the final series of measurements was completed, the bottles that had been stored at $-30^{\circ} \mathrm{C}$ and $4{ }^{\circ} \mathrm{C}$ were left at room temperature for $72 \mathrm{~h}$. A $10 \mu \mathrm{l}$ portion from each haemolysate was plated out on to blood agar and incubated at $32^{\circ} \mathrm{C}$ for $72 \mathrm{~h}$. Bacterial growth did not occur on any of the plates.

\section{Discussion}

The addition of ethanediol to the haemolysate, which is a simple and inexpensive procedure, evidently eliminated the need for membrane filtration or other special techniques designed to prevent bacterial contamination.

The oxyhaemoglobin haemolysate stored under oxygen at $-30^{\circ} \mathrm{C}$ and $4^{\circ} \mathrm{C}$ appeared to have reason-

Table 1 Haemoglobin content ( $\mathrm{g} / \mathrm{dl}$ ) of carboxyhaemoglobin haemolysate over 165-week period, measured as haemiglobincyanide

\begin{tabular}{|c|c|c|c|c|c|c|c|c|c|}
\hline \multirow[t]{3}{*}{ Material } & \multicolumn{9}{|c|}{ Period of storage (wk) and temperature } \\
\hline & \multicolumn{3}{|l|}{3} & \multicolumn{2}{|l|}{12} & \multicolumn{2}{|l|}{38} & \multicolumn{2}{|l|}{165} \\
\hline & $-30^{\circ} \mathrm{C}$ & $4^{\circ} \mathrm{C}$ & $R T$ & $-30^{\circ} \mathrm{C}$ & $4^{\circ} \mathrm{C}$ & $-30^{\circ} \mathrm{C}$ & $4^{\circ} \mathrm{C}$ & $-30^{\circ} \mathrm{C}$ & $4^{\circ} \mathrm{C}$ \\
\hline HbCO 1A (ampoule) & $19 \cdot 3$ & $19 \cdot 4$ & $19 \cdot 3$ & $19 \cdot 6$ & $19 \cdot 3$ & $19 \cdot 4$ & $19 \cdot 8$ & $19 \cdot 2$ & *NR \\
\hline $1 \mathrm{~B}$ (bottle) & $19 \cdot 3$ & $19 \cdot 3$ & $19 \cdot 3$ & $19 \cdot 3$ & $19 \cdot 3$ & $19 \cdot 3$ & $19 \cdot 9$ & $19 \cdot 7$ & *NR \\
\hline $2 \mathrm{~A}$ & - & $\ldots$ & - & $19 \cdot 4$ & $19 \cdot 4$ & $19 \cdot 3$ & $19 \cdot 3$ & $19 \cdot 0$ & $19 \cdot 6$ \\
\hline $2 \mathrm{~B}$ & $\ldots$ & 一 & - & $19 \cdot 6$ & $19 \cdot 3$ & $19 \cdot 3$ & $19 \cdot 5$ & $19 \cdot 7$ & $20 \cdot 0$ \\
\hline $3 \mathrm{~A}$ & - & - & - & - & - & $19 \cdot 3$ & $19 \cdot 2$ & $19 \cdot 1$ & $19 \cdot 7$ \\
\hline $3 B$ & - & - & - & - & - & $19 \cdot 3$ & $19 \cdot 2$ & $19 \cdot 8$ & $19 \cdot 4$ \\
\hline Remaining ampoules & - & - & - & - & - & - & - & $19 \cdot 1(n=4)$ & $19 \cdot 3(n=8)$ \\
\hline Remaining bottles & - & - & 一 & 一 & 一 & - & - & $19 \cdot 4(n=7)$ & $19 \cdot 3(n=8)$ \\
\hline
\end{tabular}

*No remaining sample.

Table 2 Haemoglobin content ( $g / d l)$ of oxyhaemoglobin haemolysate over 165 week period, measured as haemiglobincyanide

\begin{tabular}{|c|c|c|c|c|c|c|c|}
\hline \multirow[t]{3}{*}{ Material } & \multicolumn{7}{|c|}{ Period of storage (wk) and temperature } \\
\hline & \multicolumn{3}{|l|}{8} & \multicolumn{2}{|l|}{38} & \multicolumn{2}{|l|}{165} \\
\hline & $-30^{\circ} \mathrm{C}$ & $4^{\circ} \mathrm{C}$ & $R T$ & $-30^{\circ} \mathrm{C}$ & $4^{\circ} \mathrm{C}$ & $-30^{\circ} \mathrm{C}$ & $4^{\circ} \mathrm{C}$ \\
\hline $\mathrm{HbO}_{2} 1 \mathrm{~A}$ (ampoule) & $19 \cdot 0$ & $19 \cdot 0$ & $18 \cdot 9$ & $19 \cdot 0$ & $19 \cdot 2$ & $19 \cdot 1$ & $20 \cdot 1$ \\
\hline $1 \mathrm{~B}$ (bottle) & $19 \cdot 0$ & $18 \cdot 7$ & $18 \cdot 7$ & $19 \cdot 1$ & $19 \cdot 0$ & $19 \cdot 1$ & $19 \cdot 7$ \\
\hline $2 \mathrm{~A}$ & - & - & - & $19 \cdot 1$ & $19 \cdot 2$ & $19 \cdot 1$ & $19 \cdot 4$ \\
\hline $2 \mathrm{~B}$ & - & - & - & $19 \cdot 4$ & $19 \cdot 2$ & $19 \cdot 1$ & $18 \cdot 9$ \\
\hline Remaining ampoules & - & - & - & — & - & *NR & $19 \cdot 25(n=2)$ \\
\hline Remaining bottles & 一 & - & - & - & 一 & *NR & $19 \cdot 55(\mathrm{n}=2)$ \\
\hline
\end{tabular}

*No remaining samples. 
able stability for at least three years when measured by the haemiglobincyanide method, but there was a trend towards an apparent small increase in haemoglobin concentration as judged by the known reproducibility of the method $(0.7 \%) ;^{5}$ this increase may have been an artefact of incipient turbidity. The increase was greater if air was not rigorously excluded by an oxygen overlay.

At room temperature $\left(11-26^{\circ} \mathrm{C}\right)$, the preparation was stable for $8 \mathrm{wk}$, as measured with the haemiglobincyanide method but had deteriorated by $38 \mathrm{wk}$. At $40^{\circ} \mathrm{C}$, the preparation was stable for $24 \mathrm{~h}$ but had deteriorated by $72 \mathrm{~h}$.

The carboxyhaemoglobin haemolysate stored under nitrogen at $-30^{\circ} \mathrm{C}$ or $4^{\circ} \mathrm{C}$ was found to be unconditionally stable for at least three years. When the nitrogen overlay was removed, haemiglobin formed and the haemoglobin concentration, as measured by the haemiglobincyanide method, apparently increased.

The carboxyhaemoglobin haemolysate with nitrogen overlay satisfied the criteria of Lewis, ${ }^{2}$ as outlined above, for an ideal lysed blood reference material. It does have the disadvantage, when used with the ICSH diluent, of requiring two hours for complete conversion into haemiglobincyanide compared with a 3-5 min conversion time for blood samples which normally contain less than $3 \%$ carboxyhaemoglobin. However, complete conversion of the carboxyhaemoglobin haemolysate appears to take place in under one minute in the Coulter counter $\mathbf{S}$ when Isoton II and Lyse $\mathbf{S}$ are used as the diluent, but the kinetics of the conversion were not investigated.

The ICSH recommended diluent for haemiglobincyanide has been used extensively since it was proposed by van Kampen and Zijlstra in $1961 .^{9}$ However, shortcomings have been reported and various modifications suggested. Franzini et $\boldsymbol{l}^{10}$ and Matsubara et al $^{11}$ proposed the addition of sodium chloride to reduce the incidence of turbidity due to abnormal plasma proteins and/or an increased number of circulating white blood cells. Zweens et al $^{12}$ examined the changes induced by freezing the reagent and proposed the addition of ethanol to extend the shelf life. Van Assendelft et al ${ }^{1}$ acknowledged that the potassium cyanide in the reagent has poor long term stability and its concentration needs monitoring. The recommended conversion time of 3-5 $\mathrm{min}$ is in practice too long for both automated equipment and busy clinic estimations. A revised reagent, akin to the Coulter formulation in its speed of reaction, is now required.

In our judgement, the carboxyhaemoglobin haemolysate under nitrogen would have a distinct advantage over commercial haemolysates for interand intralaboratory quality control where there are long or difficult lines of communication, provided that the material is not exposed to unduly high ambient temperatures for long periods in transit and that the importance of maintaining the integrity of the nitrogen overlay is recognised.

The authors thank Drs SS Brown and FL Mitchell for advice and encouragement.

\section{References}

Van Assendelft OW, Buursma A, Holtz AH, Van Kampen EJ, Zijlstra WG. Quality control in haemoglobinometry with special reference to the stability of haemiglobincyanide reference solutions. Clin Chim Acta 1976;70: 161-9.

${ }^{2}$ Lewis SM. Standards and reference preparations. Quality control in haematology. Academic Press, 1975:79.

${ }^{3}$ Rideout JM. Report of WHO-sponsored trial of MonA and PotLab colorimeters. J Automatic Chem 1979;1: 223-4.

4 Brown SS. Laboratory support for rural health care. Proc $R$ Soc Lond B 1979;209:119-28.

5 Rideout JM, Renshaw A, Snook M. SwizzleStick: a novel positive displacement microlitre dilution device. Anal Biochem 1978;90:744-51.

- International Committee for Standardization in Haematology (ICSH). Recommendations for reference method for haemoglobinometry in human blood (ICSH Standard EP 6/2 1977) and specifications for international haemoglobincyanide reference preparation (ICSH Standard EP 6/3 1977). J Clin Pathol 1978;31:139-43.

${ }^{7}$ Rideout JM. A comparison of the performance of different makes of pipette tips on a range of Eppendorf pipettes. Med Lab Technol 1975;32:321-8.

${ }^{8}$ Van Kampen EJ, Zijlstra WG. Determination of haemoglobin and its derivatives. Adv Clin Chem 1975;8:141-87.

9 Van Kampen EJ, Zijlstra WG. Standardisation of haemoglobinometry II. The haemiglobincyanide method. Clin Chim Acta 1961 ;6:538-44.

${ }^{10}$ Franzini C, Morosini PL, Vanzetti G. A comparison between the azide-methaemoglobin and cyanmethaemoglobin methods on 268 pathological blood specimens. In: Astaldi G, Sirtori C, Vanzetti G, eds. Standardization in haematology. Milan: Franco Angeli Editore, 1970: 268.

11 Matsubara T, Okuzono H, Tamagawa S. Proposal for an improved reagent in the haemoglobincyanide method. In: Izak G, Lewis SM, eds. Modern concepts of haematology. Academic Press, 1972:29.

12 Zweens J, Frankena H, Zijlstra WG. Decomposition on freezing of reagents used in the ICSH-recommended method for the determination of total haemoglobin in blood; its nature, cause and prevention. Clin Chim Acta 1979;91:337-52.

Requests for reprints to: Mr JM Rideout, Division of Clinical Chemistry, Watford Road, Harrow, Middlesex HA1 3UJ, England. 